<総 説 $>$

(受理 : 平成 19 年 9 月 6 日)

\title{
微粒子添加によるエポキシ樹脂強勒化のメカニズム Toughening Mechanisms on Epoxy Resins with Polymer Particles
}

\section{1.はじめに}

分子間架橋により分子銷のすべりを拘束している熱硬化 性樹脂は, 線状高分子が物理的に絡み合う熱可塑性樹脂に 比較して耐溶㓮性，耐熱性や耐クリープ性が優位にあり， その意味では構造材としての信頼性がある。しかしながら， 架橋による分子運動拘束は分子鎖のすべり・塑性变形の抑 制にむつながるため，外部エネルギー吸収能力を低下させ 脆性破壊しやすい樹脂になりやすく，この点では信頼性に 不安がある。そこで, 架橋樹脂の特徴である耐候性を維持 しつつ破壊靭性を向上させるべく，種々の改質検討がなさ れてきた。

本稿では接着剤や䄉維強化複合材料のマトリックス樹脂 として構造用途に適用されているエポキシ樹脂を例にとり， 微粒子分散型の改質を行った樹脂の強勒化メカニズムにつ いて解説する。特に, 改質剤種や樹脂/改質剤界面接着性 を変えた場合の变形・破壊様式が顕微鏡的にどのように変 化するかに着目し, 勒性との関係について述べたい。

\section{2. 材料の変形・破壊様式は与えられる応力場に 応じて変化する}

改質剤添加によるエポキシ樹脂強勒化について述べる前 に，まず未改質のエポキシ樹脂の破壊様式を見たい。図 1 はジアミノジフェニルスルホン（DDS）硬化ビスフェノー ル $\mathrm{A}$ 型エポキシ樹脂の勒性評価後の破断面（予備き裂先 端領域）である。図中の矢印は破壊進展方向を示す（以下， 破断面もしくは試験片側面写真中に示す矢印も同様に破壊 進展方向を示す)。破壊勒性值 $\mathrm{K} 1 \mathrm{c}$ は $0.5 \mathrm{MPa} ・ \mathrm{~m}^{1 / 2}$ であ り, 破断面に細かなラインは認められるむのの全体に平滑

* 兵庫県立大学大学院工学研究科機械系工学専攻 兵庫県姫路市書写 2167 \% 671-2201

Himeji Institute of Technology, University of Hyogo 2167, shosha, Himeji-shi, Hyogo, 671-2201 Japan

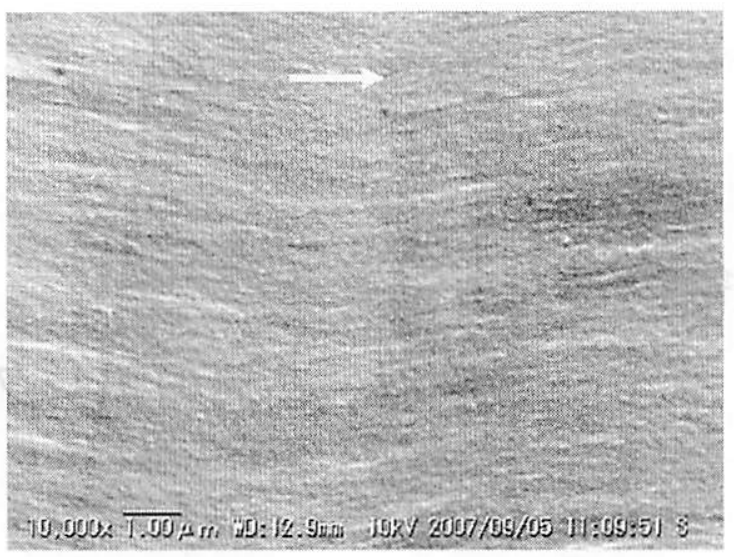

図 1 ジアミノジフェニルスルホン (DDS) 硬化エポキシ 樹脂硬化物の破断面

な脆性破壊様式を示している。一方, 図 2 は DDS 硬化ビ スフェノール A 型エポキシ樹脂について, 1 軸圧縮試験 を行い応力ー歪曲線を描いたものである。引張荷重下や破 壊靯性評価（3 軸引張応力下）においてはマクロに見ると 数\%歪んだだけで脆性破壊してしまう高架橋密度エポキシ 樹脂でさえ, 圧縮荷重下においては降伏挙動を示し, 数十 \%歪むまで破断せずに持ちこたえることがわかる。円柱状

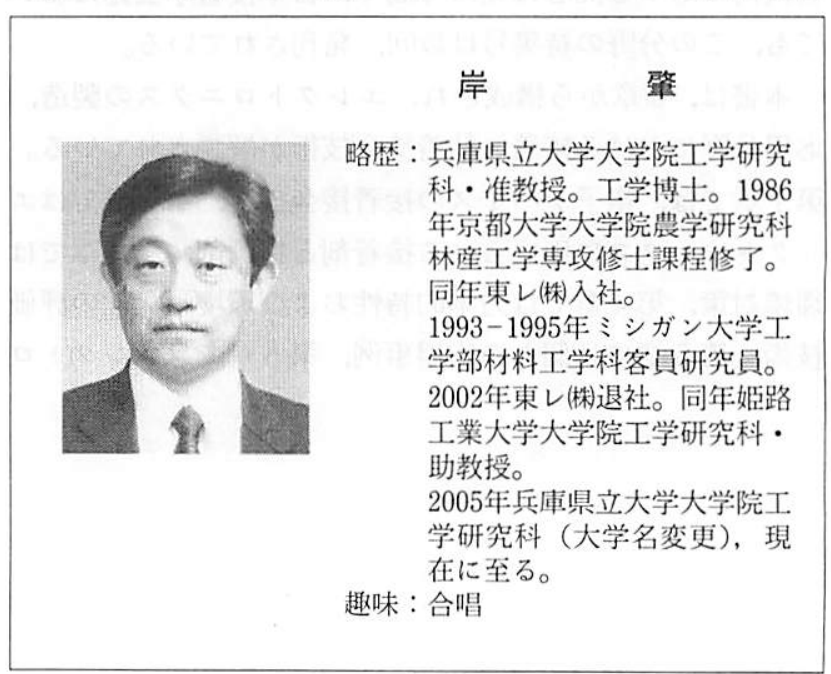


試験片の破壊後のフラグメントを観察したものが図 3 であ る1)。カップコーン型のフラグメントが残っている（図 3a） のは, 外部荷重は 1 軸圧縮であって屯実際の破断は最大剪 断応力成分が働く方向に生じたためと考えられる。その破 断面（カップコーン表面）を拡大すると流動線（フローラ イン）状の塑性变形様式が観察できる（図 3b）。分子鎖が

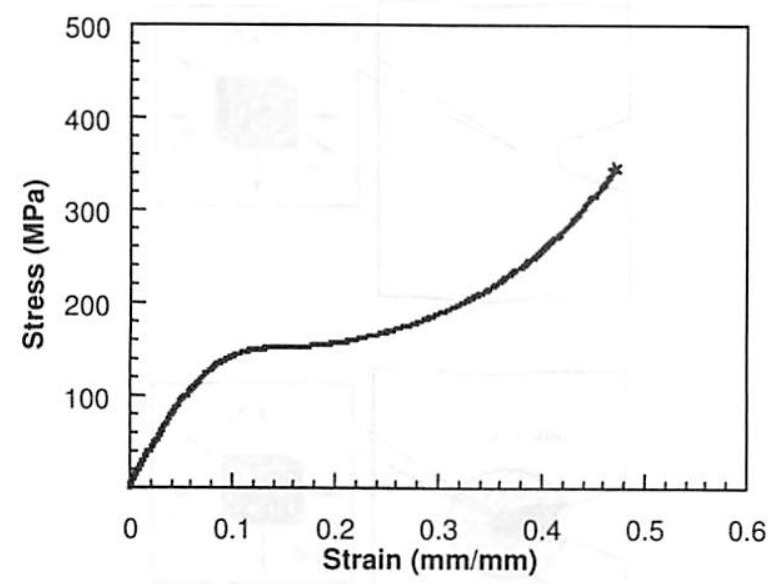

図 2 ジアミノジフェニルスルホン (DDS) 硬化エポキシ 樹脂の圧縮応力ー歪み曲線

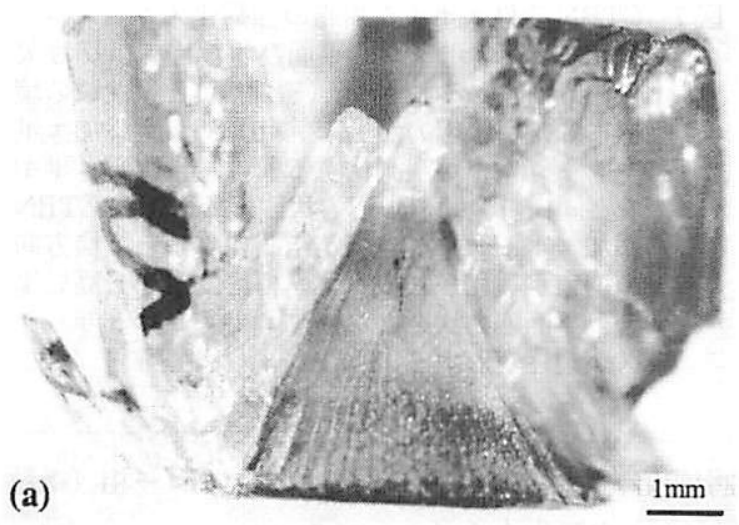

図 3 (a) ジアミノジフェニルスルホン (DDS) 硬化エポキシ 樹脂の圧縮破壊試験片 1)

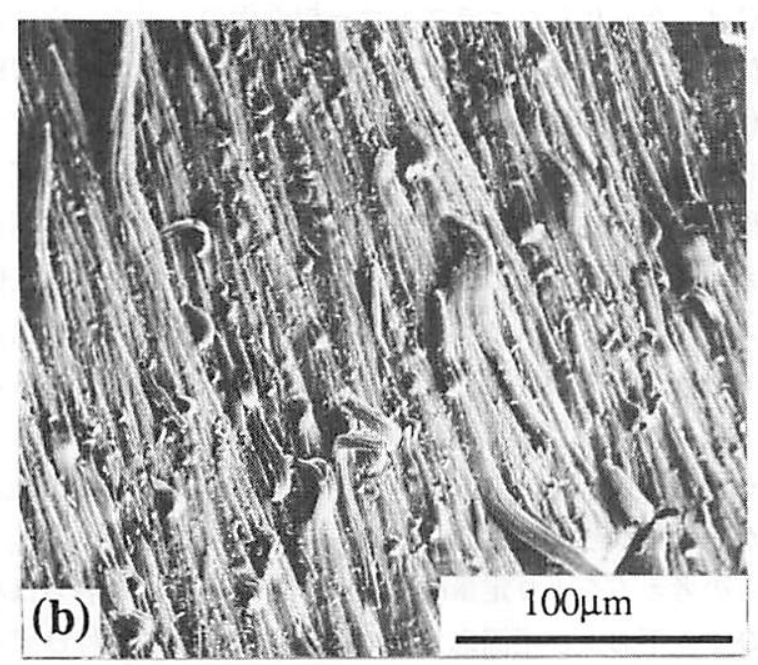

図 3 (b) 上記エポキシ樹脂圧縮破壊試験片破断面の拡大図 ${ }^{1)}$
高度に架橋されたエポキシ樹脂でさえ，与えられる応力場 次第でこのように延性的にふるまい大塑性变形を生じうる ことが興味深い。そして, こうした応力場変化による変形・ 破壊様式の変化を, 次項に述べる強勒化手法は積極的に用 いている。

\section{3. 粒子空洞化や界面はく離による応力变化が樹脂 の潜在的塑性变形能力を引き出す}

コアーシェル型ゴム微粒子を添加したジシアンジアミド (DICY) 硬化エポキシ樹脂の破断面（き裂進展の初期領 域にあたる“プロセスゾーン”) 拡大像を図 4 に示した。 未改質樹脂の $\mathrm{K} 1 \mathrm{c}$ は $0.8 \mathrm{MPa} \cdot \mathrm{m}^{1 / 2}$ であるが，ゴム微粒 子 $10 \mathrm{phr}$ 添加樹脂の $\mathrm{K} 1 \mathrm{c}$ は $2.8 \mathrm{MPa} ・ \mathrm{~m}^{1 / 2}$ に向上した。 破断面に観察されるゴム微粒子は空洞化し, 周りのエポキ シ樹脂が大きく引き伸ばされており, 破断面全体としての 凹凸が著しい。ゴム添加エポキシ樹脂の強䩲化メカニズム はこれまで液状エラストマー添加系を中心に数多く報告さ れている ${ }^{2 \sim 9)}$ 。検討された多くの例では, エラストマー相 が球形ドメインを形成している。具体例を 1 つ引用する。

図 5 はカルボキシル基末端ブタジェンニトリルゴム (CTBN) を添加した DDS 硬化ビスフェノール A 型エポキシ樹脂に おいて, 原料エポキシオリゴマーの分子量選択により架橋 点間分子量を变化させ，破壊した樹脂試験片の側面を研磨 して薄切片化し, 光学顕微鏡観察したものである ${ }^{6)}$ 。図 $5 \mathrm{a}$ はエポキシ樹脂の架橋点間分子量が $343 \mathrm{~g} / \mathrm{mol}$, 図 $5 \mathrm{~b}$ は エポキシ樹脂の架橋点間分子量が $3600 \mathrm{~g} / \mathrm{mol}$ の場合であ る。架橋点間分子量が小さい方（図 5a）は粒子形状が真 球状に近く, 破壊表面（図 5a：樹脂の上側の縁）が比較 的平坦であり, 塑性变形は限定的である。一方, 架橋点間 分子量が大きい方（図 5b）は空洞化した粒子が周りの樹 脂とともに大きく変形し棈円形状になっており, 破壊表面 （図 $5 b$ ：樹脂の上側の縁）む凹凹が大きく最終破壊に至る までに顕著な塑性変形が生じたことがわかる。結果として の䩚性（臨界ひずみエネルギー解放率 G1c にて表現）は,

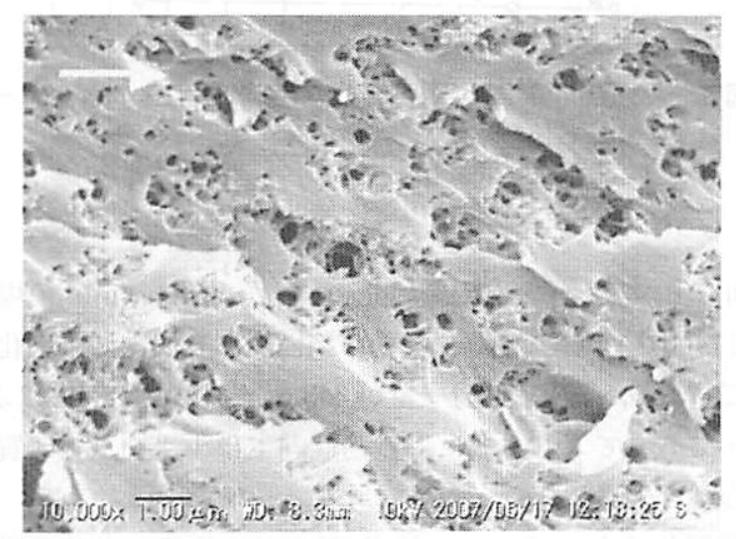

図 4 コアーシェルゴム微粒子添加エポキシ樹脂硬化物の 破断面 


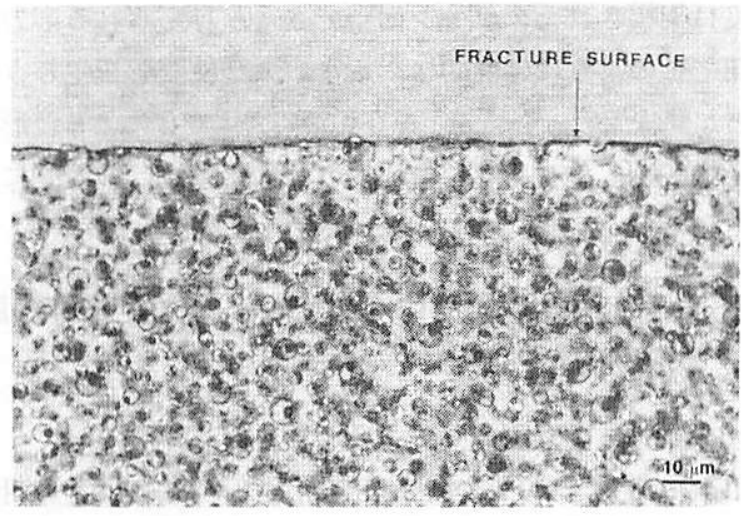

図 5 (a) CTBN 添加エポキシ樹脂硬化物の破壊試験片の 側面観察像 ${ }^{6}$ （架橋点間分子量 $343 \mathrm{~g} / \mathrm{mol}$ )

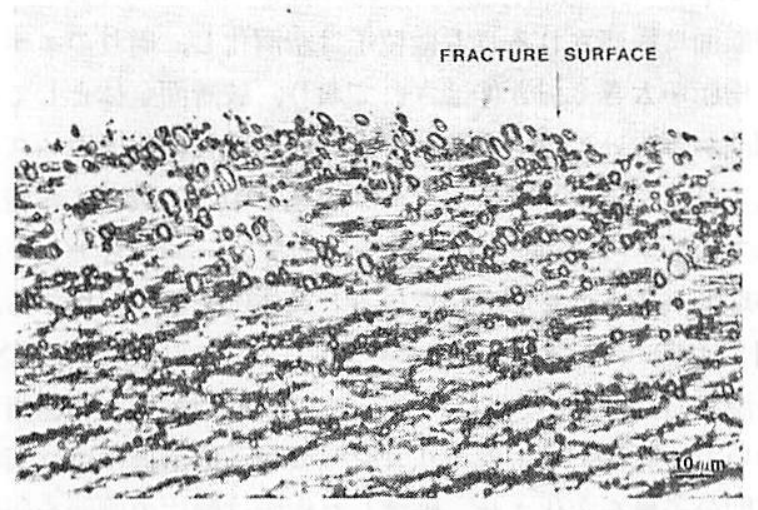

図 5 (b) CTBN 添加エポキシ樹脂硬化物の破壊試験片の 側面観察像 ${ }^{6)}$ (架橋点間分子量 $3600 \mathrm{~g} / \mathrm{mol}$ )

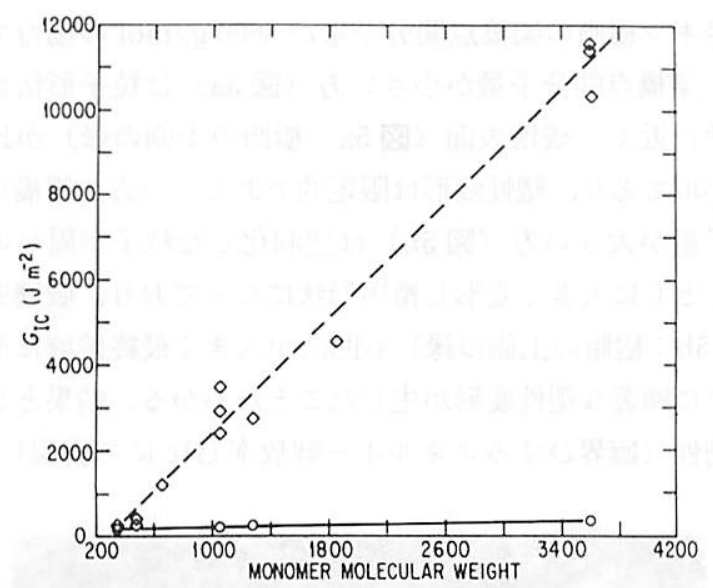

図 6 架橋点間分子量と樹脂勒性（臨界ひずみエネルギー 解放率 G1c) ${ }^{6}$

$\bigcirc:$ 未改質エポキシ樹脂,

$\diamond:$ CTBN 添加 (10\%) エポキシ樹脂

図 6 に示すように，架橋点間分子量が $3600 \mathrm{~g} / \mathrm{mol}$ の場合 は $11400 \mathrm{~J} \cdot \mathrm{m}^{-2}$ であり, 著しい塑性変形を反映し強勒化さ れているが, 架橋点間分子量が $343 \mathrm{~g} / \mathrm{mol}$ の場合は $242 \mathrm{~J}$ ・ $\mathrm{m}^{-2}$ であってゴム添加による勒性向上は小さい（未改質樹 脂の $\mathrm{G} 1 \mathrm{c}$ は $\left.162 \mathrm{~J} \cdot \mathrm{m}^{-2}\right)$ 。

強勒化メカニズムは, (1) 平面ひずみ状態にある分厚い 試験片のき裂先端（微小塑性域之弾性域の境界付近）には
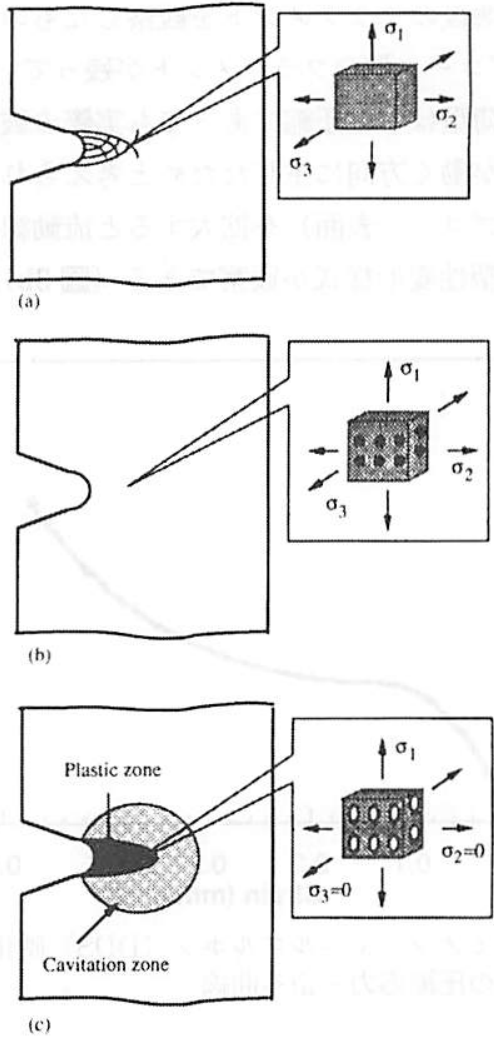

図 $7 \mathrm{CTBN}$ 変性エポキシ樹脂の強勒化メカニズム ${ }^{8)}$ (a) 未改質エポキシ：平面ひずみ場では切り欠 き先端に生じるすべり線（塑性域）と弾性域の境 界に 3 朝引張応力が働く。(b) CTBN 添加エポ キシ：ゴム相が空洞化する前は，未改質エポキ シと同様の 3 軸引張応力状態にある。(c) CTBN 添加エポキシ：ゴム相が空洞化すると, 横方向 の拘束が緩和される。ゴム相濃度が十分高い場 合，平面応力状態となり，エポキシマトリック スが塑性変形する。

3 軸引張応力が生じ, 強度の弱いエラストマー相（微粒子） 内部がまず空洞化する (キャビテーション)。(2) 空洞は樹 脂を引っ張り得ないため, 空洞化前の 3 軸性はエラストマー 相の空洞化によって弱まる。エラストマー添加量が十分多 ければ，空洞化したエラストマー相近傍のエポキシ樹脂は 全体として平面応力状態に変化する (3)こうした応力状態 変化は材料の塑性変形を容易にするため, 結果として粒子 周りの樹脂が大きく塑性変形し多くのエネルギーを吸収し 勒性が向上する (図 7) ${ }^{8)}$ というあのである。この強勒化 メカニズムの重要点の 1 つは, エネルギー吸収を担う主体 はエラストマー相 (微粒子) ではなくマトリックス樹脂自 体であり, 元来塑性変形能力の高いエポキシ樹脂であるほ ぞ（例えば，樹脂の架橋密度を下げるにつれ）, エラスト マー相 (微粒子) のキャビテーションに誘発される塑性変 形が著しくなり，勒性向上効果も高くなることである ${ }^{6)}$ 。

この考元方をより定量的に証明するために，筆者らは平 面ひずみ下および平面応力下での樹脂の局所的塑性ひずみ を定量化し比較した ${ }^{9)}$ 。用いたエポキシ樹脂組成は上記 
Pearson ら 6) の検討と同じ DDS 硬化ビスフェノールA 型 エポキシ樹脂であり，硬化条件もまったく同じである。但 し, 樹脂中の局所ひずみを定量化するために, 变形マーカー として樹脂中に微量の真球状ポリマー微粒子（ナイロン微

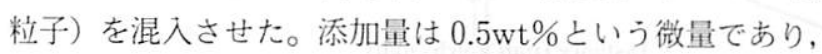
エポキシ樹脂本来の変形挙動にはほとんど影響を与えない。 ナイロン微粒子はエポキシに良分散し強固に接着して界面 はく離しないため, 元々真球状であった微粒子がマトリッ クスである樹脂の変形に伴って变形し棈円球になる様子を 顕微鏡観察すれば，粒子周囲の樹脂の局所ひずみを視覚的 に定量化できる。詳細は論文 ${ }^{9)}$ を参照いただきたいが, 切り欠き付き平板引張試験片を用いると，応力集中とひず み拘束により切り欠き底には多軸性の引張応力状態が生ま れる。但し, 試験片厚みを变えることにより応力状態は変 化し, 分厚いほど 3 軸性が強まる。また, 同じ試験片の中 でも切り欠き底からの距離が異なると応力状態は变わり,
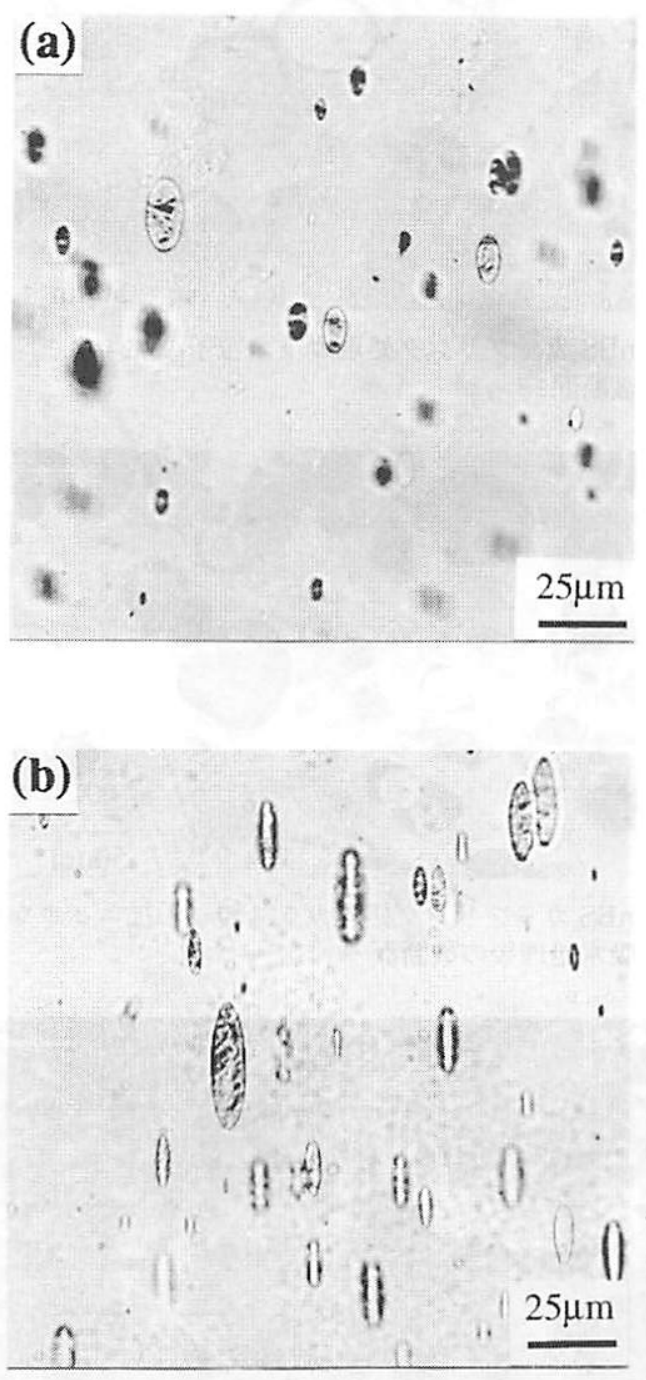

図 8 エポキシ樹脂硬化物破壊試験片切り欠き底近傍の 光学顕微鏡写.真 ${ }^{9)}$ (微量分散させたナイロン微粒子 の変形により, 塑性ひずみを定量化）
(a) 架橋点間分子量 $1050 \mathrm{~g} / \mathrm{mol}$,
(b) 架橋点間分子量 $3600 \mathrm{~g} / \mathrm{mol}$

3 軸性の違いによるひずみの変化も钼察できる。

試験片厚さが十分薄い場合, 1 軸引張荷重下において試 験片に全断面降伏が生じるが, 図 8 に（a）架橋点間分子 量 $1050 \mathrm{~g} / \mathrm{mol}$, (b) 架橋点間分子量 $3600 \mathrm{~g} / \mathrm{mol}$ の雨樹脂 の切り欠き底近傍の光学顕微鏡観察像を示した ${ }^{9)}$ 。1 軸引 張荷重下においては樹脂の架橋点間分子量增加（架橋密度 低下）に伴い破断に至るまでに生じる塑性変形が増加した ことが, 変形マーカーとしての粒子形状から視覚的にわか る。一方, 試験片厚さが十分厚ければ応力場は平面ひずみ 条件となり,すべり線型の剪断変形（塑性域）が生じる10)。 3 軸引張応力状態にあるすべり線場の先端付近（塑性域と 弾性域の境界付近）を観察したところ, 樹脂の架橋点間分 子量によらず分散粒子は真球状に保たれていた。つまり, 3 軸引張応力下では, 低架橋密度エポキシ樹脂も高架橋密 度エポキシ樹脂と同程度の塑性变形しか生じ得ないことを 示している。定量化した樹脂塑性ひずみと架橋点間分子量 の関係を図 9 に示した ${ }^{9)}$ 。同一樹脂で比較すると，1軸引 張応力 (平面応力) 下では 3 軸引張応力（平面ひずみ）下 よりはるかに塑性ひずみが大きい。また，1軸引張応力下 では樹脂架橋密度が低いほど破壊に至るまでに生じる塑性 ひずみが顕著に増加したが，3 軸引張応力下では架橋密度 低下がひずみ增加にほとんどつながらない。さて, 同様の 手法を用いエラストマー（CTBN）変性エポキシ樹脂の破 壊塑性ひずみを定量化したものが図 10 である99。分厚い 試験片を用いたにもかかわらずエラストマー变性により全 般的に塑性ひずみは増加しており, 特に力学拘束の弱い切 り欠き底に近づくほど, 架橋密度低下に伴う塑性ひずみ増 加が著しい。エラストマー変性をした場合, マクロには分 厚い試験片であっても，樹脂内部では力学拘束 (3 軸性) の緩和がエラストマー相の空洞化によりあたらされ，あた かあ薄い試験片に近い応力状態になった結果, 塑性ひずみ が増加したと考えられる。この架橋密度と塑性変形能力と の関係は, Pearson らが示した架橋密度とエラストマー

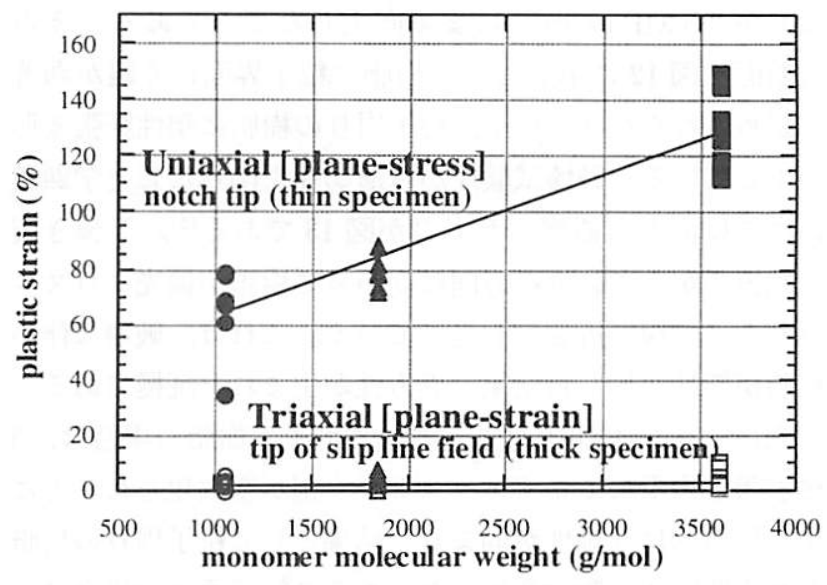

図 9 架橋点間分子量 (架橋密度) の異なるエポキシ樹脂が 破壊する時点での塑性ひずみに及ぼす応力状態の影響 97 


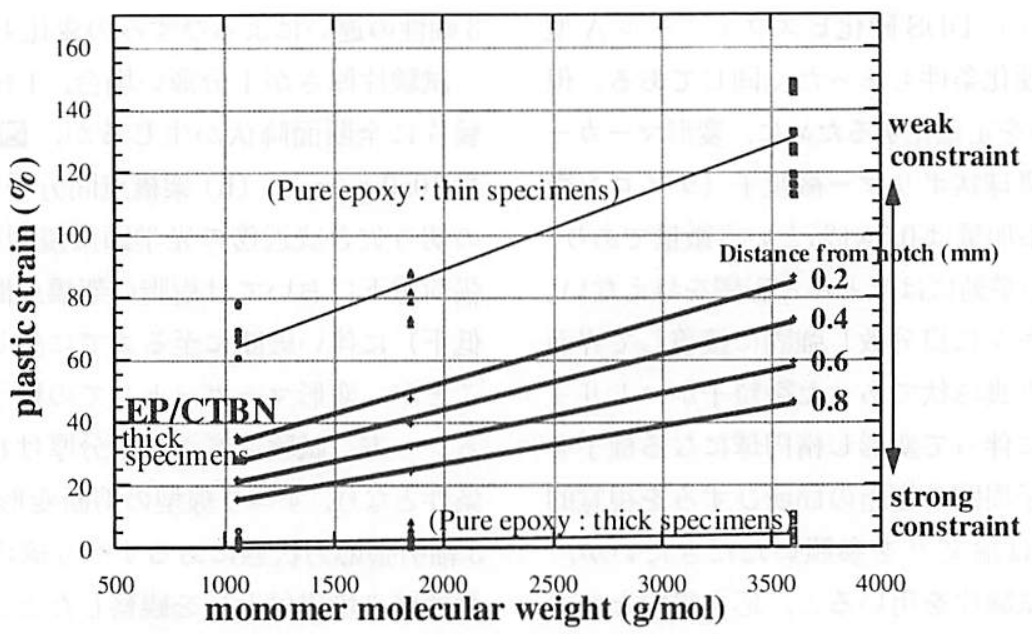

図 10 架橋点間分子量 (架橋密度) の異なる CTBN 変性エポキシ樹脂が破壊する時点での塑性ひずみ ${ }^{9}$ ) （架橋点間分子量が小さいほど，また，切り欠き底からの距離か力離れるほど，破壊時の塑性ひずみは小さい）

添加樹脂強勒化勃果の関係（図 6 ${ }^{6)}$ とまったく同傾向で ある。エポキシ樹脂が元来有する塑性変形能力こそが, エラストマー添加による樹脂強勒化の大小を決定する “toughenability”であることを定量的に示すあのである。 また，エラストマー相（の空洞化）は，塑性変形に有利な 応力状態（3 軸性の緩和）を樹脂内部にもたらす 1 つの仕 掛けである。

改質剤粒子の物性がエラストマー粒子とはまったく異な るガラス粒子添加系でも, 樹脂自体の塑性変形能力を引き 出す類似メカニズムによりエポキシ樹脂強勒化が可能であ ることが報告されている11,12)。図11はn-ブチルトリメト キシシラン (nBS) カップリング剤で表面処理したガラス 粒子を添加したピペリジン硬化ビスフェノール A 型エポキ シ樹脂の破断面である ${ }^{12}$ 。このシランカップリング剤はエ ポキシ樹脂との反応性がなく，破断面のガラス粒子表面は 露出しており，樹脂／粒子界面接着性が乏しいために破壊 進展時に界面はく離が生じたと思われる。 K1c は $2.0 \mathrm{MPa} ・$ $\mathrm{m}^{1 / 2}$ であり, 未添加樹脂の $\mathrm{K} 1 \mathrm{c} 1.2 \mathrm{MPa} \cdot \mathrm{m}^{1 / 2}$ より顕著 に向上していた。さらに興味深いのは, 吸水処理により $\mathrm{K} 1 \mathrm{c}$ が $2.5 \mathrm{MPa} ・ \mathrm{~m}^{1 / 2}$ にまで向上したことである。その 破断面を図 12 に示した ${ }^{12)}$ 。樹脂／粒子界面はく離が顕著 に認められるだけでなく, 粒子周りの樹脂に塑性膨張变形 が生じている。破壊試験片から薄切片を削りだし光学顕微 鏡にて側面から観察したものが図 13 である12)。予備き裂 先端箇所からき裂進行方向に向かって樹脂が偏光クロスニ コル下にて複屈折を示し光っている。これは, 破壊に伴い 樹脂が塑性変形した結果，異方性が生まれた証拠である。

先に述べたエラストマー添加エポキシ樹脂の場合は，3 軸引張応力下にてまずェラストマー相が空洞化したことに より局所的に 3 軸性が弱まり，結果として粒子周りの樹脂 がせん断降伏・塑性変形した。ガラス粒子添加の場合は, 樹脂／粒子界面のはく離が類似の応力状態变化をもたらす

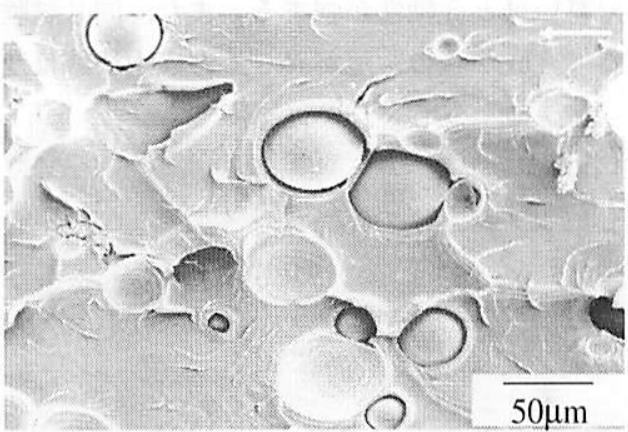

図 $11 \mathrm{nBS}$ カップリング処理ガラス粒子添加エポキシ樹脂の 破断面 ${ }^{12}$

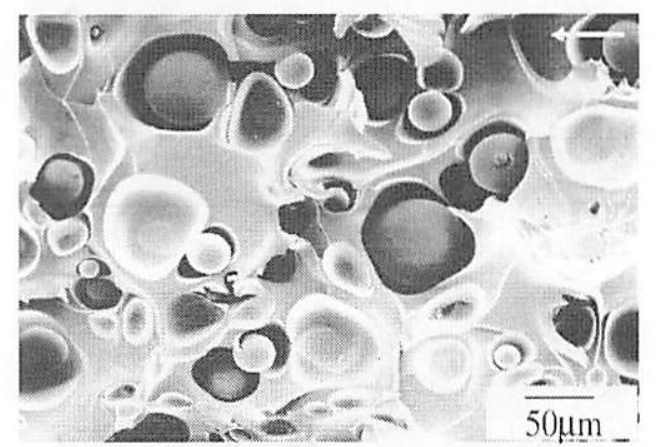

図 $12 \mathrm{nBS}$ カップリング処理ガラス粒子添加エポキシ樹脂の 吸水処理後の破断面 ${ }^{12)}$

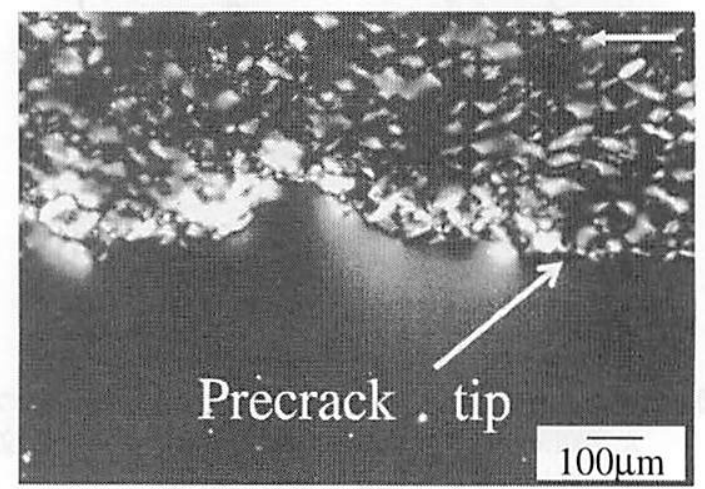

図 $13 \mathrm{nBS}$ カップリング処理ガラス粒子添加樹脂の吸水処理 後破壊試験片の側面観察像 ${ }^{12)}$ (クロスニコル下) 
トリガーとして働き, 結果として樹脂塑性変形を促進し強 勒化をむたらしたと考えられる。言い換えると，樹脂／粒 子間接着性の抑制が勒性向上効果を導いたことを示してい る。実際, アミノプロピルトリメトキシシラン (APS) カッ プリング剤表面処理によりガラス粒子とエポキシ樹脂との 接着性を良好にすると, 強勒化効果が減少し, 塑性変形屯 限定的であったことが報告されている ${ }^{12)}$ 。同ガラス粒子添 加樹脂について，ガラス粒子とエポキシ樹脂との界面接着 性の差による破壊様式の変化が耐疲労性に影響を与えるこ

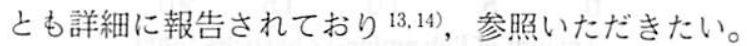

エラストマー粒子添加による強勒化では添加量に応じ必 然的に樹脂全体の剛性が低下するが，ガラス粒子（剛直粒 子）添加の場合は樹脂全体の剛性はむしろ向上することが 特徵である。但し，上記したガラス微粒子添加による強勒 化効果の大小は, エラストマー添加の場合と同様に, マト リックスとなる樹脂自体が元来有する塑性変形能力を引き 出す強勒化メカニズムであるため, 樹脂組成にも大きく依 存すると考えられる。同じ基本化学構造の樹脂を考えると, 架橋密度低下により “toughenability” は向上するが， Tg， 耐熱性が低下してしまう。したがって，このメカニズムに よる強勒化と高耐熱性を雨立させるためには，低架橋密度 であってもなお高 $\mathrm{Tg}$ を与えるような，たとえば剛直ある いは高極性な樹脂基本骨格を選択する必要があると考えら れる。

\section{4. マトリックスとなる樹脂の塑性変形能力に 頼らない強勒化メカニズム}

ポリアミド 12 粒子の添加もエポキシ樹脂強勒化に役立 つことが知られている15-17) 図 14 は, DICY 硬化ビスフェ ノール $\mathrm{A}$ 型エポキシ樹脂に直径約 $5 \mu \mathrm{m}$ のポリアミド 12 粒子を $10 \mathrm{phr}$ 添加した樹脂についての破断面観察結果で ある。 $\mathrm{K} 1 \mathrm{c}$ は $1.6 \mathrm{MPa} ・ \mathrm{~m}^{1 / 2}$ であるが, 図 14 を見るとポ リアミド粒子の中央部分が引き延ばされ, ちぎれているこ とがわかる。図 15 はポリアミド 12 粒子添加 DICY 硬化 ビスフェノール A 型エポキシ樹脂にてアルミ板を接着し, はく離応力により破壊させ, き裂進展の途中を側面から光 学顕微鏡観察したものであるが, き裂進展中の破壊上下面 をポリアミド粒子がブリッヂングしていることがわかる16)。 粒子ブリッヂングによりき裂進展を抑制し, 最終的には十 分塑性変形した後に引きちぎられるといったプロセスにて

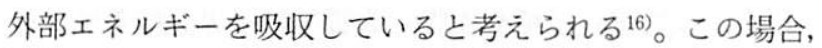
エネルギー吸収を担っている主体はマトリックスとしての エポキシ樹脂ではなく，添加されたポリアミド粒子である。 したがって, 先のエラストマー微粒子添加系とは異なり, 強勒化効果を高めるためにマトリックス樹脂の架橋密度を 低下させる必要はなく，樹脂の耐熱性を維持したまま強靭 化可能なことが特徴である。

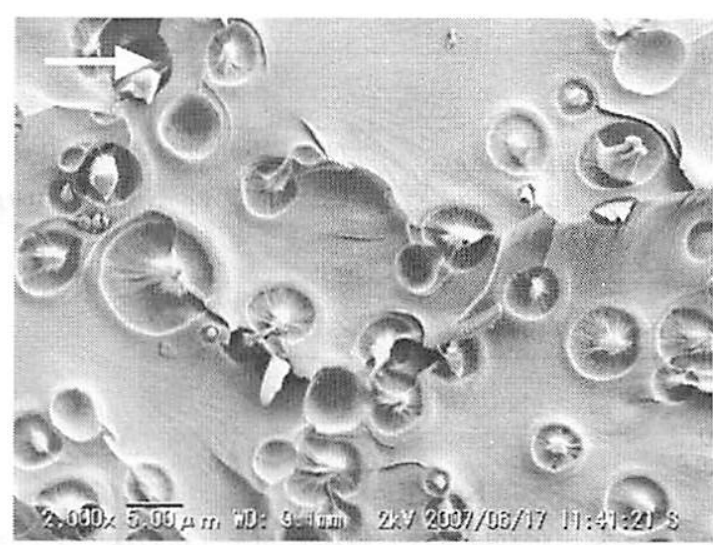

図 14 ポリアミド 12 粒子添加エポキシ樹脂硬化物の破断面

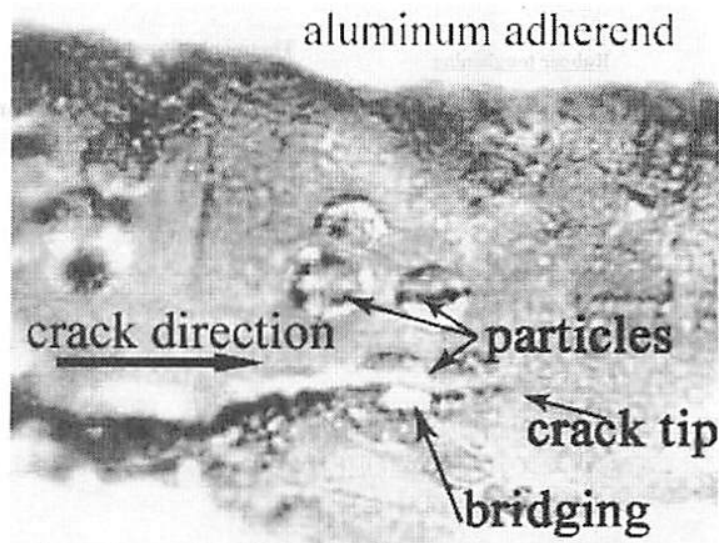

aluminum adherend

図 15 ポリアミド 12 粒子添加エポキシ樹脂接着層の 側面観察像 ${ }^{16)}$

こうした強勒化メカニズムの違いは，接着剤として用い た場合に接着層厚み依存性の差としても重要な意味を持つ。 すなわち, 被着体と界面はく離せず樹脂内凝集破壊が生じ る場合，接着剤樹脂の勒性向上は，定性的にはいずれの 改質手法を用いたとしてもはく離接着力向上につながる が，その向上程度が改質剤粒子種と接着層厚みによって異

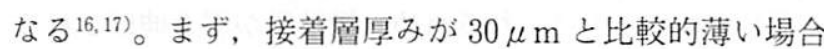
である。ポリアミド 12 粒子添加樹脂では, 樹脂䩲性向上 が剥離接着力向上に大きな効果があり，20phr 添加におい てはく離接着強さは約 $200 \mathrm{~N} / 25 \mathrm{~mm}$ 幅に達した。これは, 未改質樹脂の約 3 倍にも相当する。しかし，コアーシェル ゴム粒子添加樹脂では樹脂靯性向上効果はポリアミド 12 粒子添加より顕著であるにもかかわらず，はく離接着強さ 向上が約 $130 \mathrm{~N} / 25 \mathrm{~mm}$ 幅にて頭打ちとなった（図 16）。い ずれのはく離接着試験片む樹脂単独（勒性測定時）の場合 と類似した破断面を示していたにもかかわらず，はく離接 着力と樹脂勒性で改質剤添加効果の序列が逆転している ${ }^{16)}$ そこで，ゴム粒子添加樹脂とポリアミド 12 粒子添加樹脂 について, バルク樹脂破壊靱性試験とはく離接着試験にお ける破壊メカニズムを比較考察したものを図 17 に示す ${ }^{17)}$ 


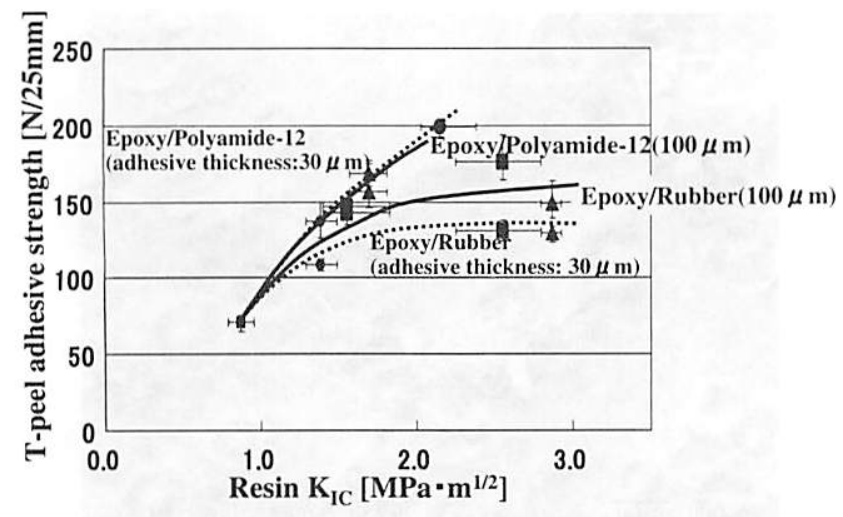

図 16 接着剤樹脂勒性とはく離接着強さ（被着体：アルミニ ウム）の関係 ${ }^{17)}$ (強勒化手法によって接着層厚み依存 性が異なる)

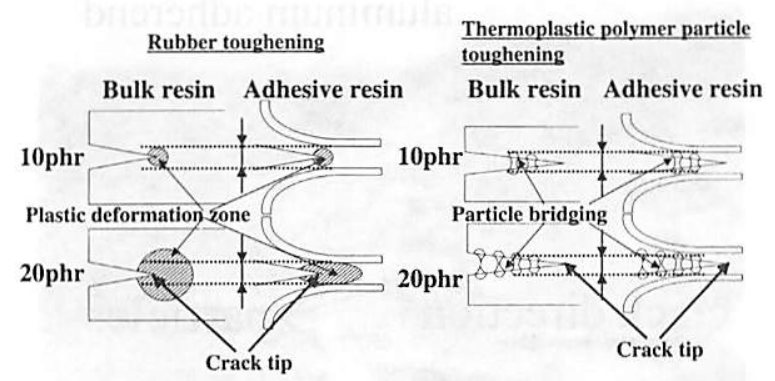

図 17 バルク樹脂強勒化手法別のはく離接着強さ向上 メカニズム ${ }^{17)}$ (強䩲化手法によって被着体による 变形拘束度が異なる)

既存のゴム微粒子添加技術は，進展クラック先端より前方 の樹脂塑性变形によりエネルギー吸収を起こすと考えられ る。そのため, 樹脂塑性变形領域の厚みは接着層厚みを超 えることができない。したがって，被着体による樹脂变形 拘束（接着層厚み依存性）が強いと考えられる。一方，先 の破面観察結果に示されるように，ポリアミド 12 粒子添 加においては, 進展クラック先端より後方で粒子ブリッヂ ングが生じェネルギー吸収するメカニズムが主に働く。こ の場合, クラック先端より後方側では被着体（アルミニウ ム板）がめくり上げられるため，微粒子が引き伸ばされる 変位量は元の接着層厚みより大きな变位幅まで許容される。 つまり，ポリアミド 12 粒子添加系は，クラック後方のブ リッヂングによる強䩲化であるゆえ，被着体による变形拘 束（接着層厚み依存性）が小さく, 顕著なはく離接着強さ 向上をもたらしたと解釈できる。

実際，ゴム粒子添加系において接着層厚みを $100 \mu \mathrm{m}$ ま で増加させると，はく離接着強さが頭打ちとなるゴム添加 量（樹脂勒性）は高濃度側（より高勒性側）へシフトし, 到達はく離接着強さは約 $170 \mathrm{~N} / 25 \mathrm{~mm}$ 幅へと向上した （図 16）。一方，ポリアミド微粒子添加系は接着層厚みが $30 \mu \mathrm{m}$ でも $100 \mu \mathrm{m}$ でむはく離接着強さはほとんど変わ らず $20 \mathrm{phr}$ 添加にて約 $200 \mathrm{~N} / 25 \mathrm{~mm}$ 幅の高はく離接着強 さとなり，接着層厚み依存性が小さい（図 16） ${ }^{17) 。 ~}$

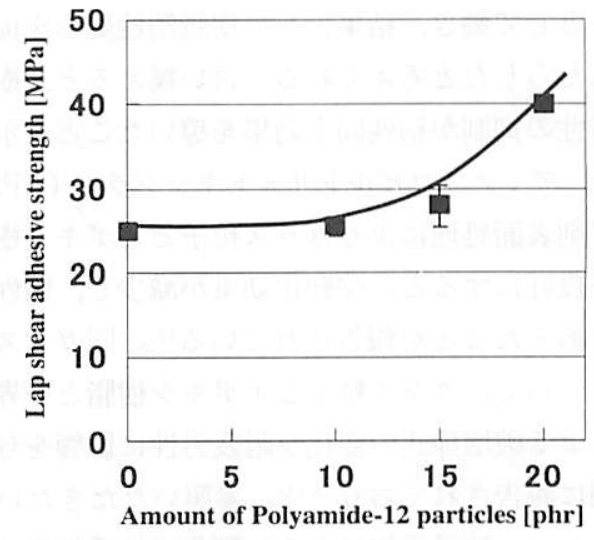

図 18 ポリアミド 12 粒子添加によるエポキシ樹脂せん断 接着強さの变化 ${ }^{16)}$

ちなみに，はく離接着強さとは負荷方向の異なる接着特 性であるせん断接着強さについて，ポリアミド 12 粒子添 加効果を評価した結果を図 18 に示す。ポリアミド 12 粒子 の $15 \mathrm{phr}$ 以上の添加によりせん断接着強さむ向上し， $20 \mathrm{phr}$ 添加樹脂においては $40 \mathrm{MPa}$ む高接着強さを示し た ${ }^{16)}$ 。

上記したように，ポリマー粒子添加による破壊靭性向上 メカニズムは, マトリックスとなるエポキシ樹脂の塑性変 形能力に依存しておらず，ポリマー粒子自体の強勒性が用 いられている。その意味でポリアミド 12 でなければなら ないということではなく，他のエンジニアリングプラスチッ クの微粒子であ同様の強勒化メカニズムが働く可能性は高 い。また，前述のエラストマー粒子添加による強勒化メ力 ニズムとは異なり, マトリックス樹脂の塑性変形能力に頼 らない強勒化メカニズムであるため, 高架橋密度・高耐熱 性で塑性変形能力のそしい樹脂を強勒化できるという意味 で，汎用性のある技術といえる。但し，ブリッジングメカ ニズムが働くためには，粒子／樹脂間の良好な界面接着性 は必須要素となるので, 界面接着の観点からポリマー素材 の組み合わせへの制約はある。また，詳細は論文を参照い ただきたいが，ポリマー素材の弾性率がマトリックス樹脂 の弾性率より小さい方が，ポリマー粒子が適度な応力集中 点としてクラックを誘導し，ブリッヂング剂としてのポリ マー粒子の利用効率を高めると考えられる ${ }^{17)}$ 。粒子素材ポ リマー自体の䩲性と，エポキシ樹脂勒性改質剂として用い た場合のはく離接着強さの関係についても, 定量的な考察 がなされている17)。

以上, 改質剂粒子種や樹脂／改質剂粒子界面接着性の違 いにより，エポキシ樹脂の破壊勒性や接着強さが变化する メカニズムを解説した。取り上げた例は，これまで多くの 研究者により為されてきた膨大な強勒化検討の一部に過ぎ ないが, 変形・破壊様式を詳細に観察し帰納的に考察して 体系化することが，種々の技術の適切な用法と限界を理解 するために重要である。 


\section{引用文 献}

1) H. Kishi, Y-B. Shi, J. Huang and A. F. Yee, J. of Mater. Sci., 32, 761 (1997)

2) A. J. Kinloch, S. J. Shaw, D. A. Tod and D. L. Hunston, Polymer 24, 1341 (1983)

3) A. J. Kinloch and D. L. Hunston, J. Mater. Sci. Lett. 5, 909 (1986)

4) A.F. Yee and R. A. Pearson, J. Mater. Sci. 21, 2462 (1986)

5) R.A.Pearson and A.F. Yee, J. Mater. Sci. 21, 2475 (1986)

6) R.A.Pearson and A.F. Yee, J. Mater. Sci. 24, 2571 (1989)

7) H-J. Sue and A. F. Yee, J. Mater. Sci. 24, 1447 (1989)

8) A. F. Yee, D. Li and X. Li, J. Mater. Sci. 28, 6392 (1993)
9) H. Kishi, Y-B. Shi, J. Huang and A. F. Yee, J. Mater. Sci., 33, 3479 (1998)

10）成澤郁夫, “プラスチックの耐衝撃性”, (シグマ出版), pp. 40-44 (1994)

11) T.Kawaguchi and R.A.Pearson, Polymer 44, 4229 (2003)

12) T. Kawaguchi and R.A.Pearson, Polymer 44, 4239 (2003)

13) T.Kawaguchi and R.A.Pearson, Comp. Sci. Technol., 64, 1981 (2004)

14) T. Kawaguchi and R. A. Pearson, Comp. Sci. Technol., 64, 1991 (2004)

15) B. Cardwell and A. F. Yee, J. Mater. Sci. 33, 5473 (1998)

16) 岸 肇, 植澤和彦, 松田 聡, 村上 憞, 日本接着学会誌, 40, 5, 177 (2004)

17) H. Kishi, K. Uesawa, S. Matsuda and A. Murakami, J. Adhesion Sci. Technol., 19, 15, 1277 (2005) 